\title{
Echocardiographic Profile of Patients in Dhulikhel Hospital, A Medical College Hospital in Nepal
}

\author{
Sanjaya Humagain, Ramsundar Twayana, Rajendra Koju \\ Department of Cardiology, Dhulikhel Hospital, Dhulikhel, Nepal
}

\section{Citation}

Sanjaya Humagain, Ramsundar Twayana, Rajendra Koju. Echocardiographic profile of patients in Dhulikhel Hospital, A Medical College Hospital in Nepal. Nepalese Heart Journal 2014;11(1): 13-17

\section{Keywords}

Congenital Heart Disease, Cor- pulmonale,

Echocardiographic profile, Ischemic Heart Disease, Rheumatic Heart Disease

\section{INTRODUCTION}

The evaluation of cardiac structure and function with images and recordings produced byultrasound is known as echocardiography ${ }^{1-3}$. Currently, echocardiography provides essential clinical information and is the second most frequently performed diagnostic procedure ${ }^{2,3}$. Echocardiographic units are also being miniaturized to become an extension of a clinician's physical examination ${ }^{4}$ The appreciation of cardiac anatomy and hemodynamics by echocardiography makes a physician's clinical evaluation more relevant to the care of patients ${ }^{2}$.

\begin{abstract}
Background and Aim : Echocardiograph is an important diagnostic tool to evaluate cardiac disease and is indispensible for management. So it is important to know the spectrum of cardiac abnormalities that can be detected by echocardiograph and the frequency of these findings may vary depending on where the echocardiogram is performed. Aim of this study was to find out the spectrum of echocardiographic finding in different age group in a medical college hospital.
\end{abstract}

Methods and materials : A retrospective observational study was done to at Dhulikhel Hospital to review Echocardiographic profile of 3310 patients who were indicated for echocardiogram over a period of 3 years. Data collected from echocardiograph report registry. Data analysis was done using SPSS 17.

Result : Congenital Heart Disease(CHD) (37.74\%),Normal finding(21.19\%), Pericardial Heart Disease(19.21\%) and Rheumatic Heart Disease (RHD)(17.88\%) were the echocardiographic finding in children. In adolescents and young adults Rheumatic Heart Disease (49.90\%), Hypertensive Heart Disease (13.34\%), Congenital Heart Disease (6.58\%), and Pericardial Disease (4.38\%) were found. Most common finding in middle age was cor-pulmonale (34.76\%) followed by Diastolic Dysfunction (20.60\%), Hypertensive Heart Disease(17.06\%), Ischemic Heart Disease(IHD) (12.80\%). In elderly age most common finding was Diastolic Dysfunction (57.14\%).

Conclusion : The spectrum of echocardiograph finding in a medical college hospital ranges from Congenital Heart Disease, Rheumatic Heart Disease, Ischemic Heart Disease ,Pericardial disease, Corpulmonale, Diastolic Dysfunction, systolic dysfunction and degenerative valve disease. Streptococcal sore throat leading to Rheumatic Heart Disease and complication of tuberculosis and parasitic infestation leading to pericardial diseases, as well as Hypertensive Heart Disease, and Ischemic Heart Disease constitutes burden in Nepal. Cor-pulmonale and) Sanjaya Humagain, Ramsundar Twayana, Rajendra Koju.

\section{Corresponding author}

Sanjaya Humagain

Department of Cardiology, Dhulikhel Hospital, Dhulikhel, Nepal. Email:sanjayahumagain@hotmail.com 
Cardiovascular Disease is the leading cause of mortality worldwide. Developing countries contributed to 80 percent of CVD deaths. There is considerable variation in CVD mortality rates across world ${ }^{5-6}$. A developing country like Nepal has to deal with communicable disease as well increasing burden of non communicable heart disease ${ }^{7}$. In both conditions echocardiography is an important evaluation tool. In the last decade echocardiography has become more popular and available in different parts of the country. In Nepal Echocardiography is mostly restricted to cardiologists, however other specialties frequently refer patients for echocardiographic evalulation. Common echocardiographic findings may vary depending on which setting it is performed. It may be different in private clinic or in cardiac center in comparison to general hospital with multiple disciplines.

So in this study, the aim was to find out the echocardiographic profile of patients at Dhulikhel Hospital, Kathmandu University Hospital. Dhulikhel Hospital is located 30 kilometer east of Kathmandu and is a medical college hospital where echocardiography is indicated by cardiologists, physicians, pediatricians and other specialists.

\section{METHOD}

This is a retrospective observational study done at Dhulikhel Hospital, Kathmandu University Hospital. Echocardiography report records from $1^{\text {st }}$ January 2011 to $31^{\text {st }}$ December 2013 were collected. Echocardiography was performed by either one of the two cardiologists present at Dhulikhel Hospital. Echocardiography were done using TOSHIBA POWER VISION 6000, according to guidelines from American Society of Echocardiography,8.

A total of 3310 echocardiogram reports were found and all were included in the study. Demographic profiles and findings were recorded. A single patient could have more than one finding. Age group was divided into 4 major groups, children up to 10 years, adolescents and young adults from 11 to 40 years, middle age from 41-60 years and elderly 61 and above.

Data analysis was done using SPSS 17, students t test was applied wherever applicable.

\section{RESULT}

The age range of patients was from $1^{\text {st }}$ day of life to 98 years with mean (SD) age 51+/- 7.2 years. Out of total number of 3310 patients $1680(50.75 \%)$ were male and $1630(49.25 \%)$ were females with no statistically significant difference, $p$ being 0.44 . However there was some statistically significant difference between male and female in some age groups as shown in table 1 . The highest number of patient was in age group 51-60. Normal echocardiographic finding was rare in elderly patients.

The most common echocardiographic finding in children was congenital heart disease (CHD), 57 out of 151(37.74\%) as given in table 2. Followed by normal finding 32(21.19\%), Pericardial disease 29(19.21\%) and Rheumatic Heart Disease (RHD) 27(17.88\%). Atrial Septal Defect (ASD) was the most common CHD (32), followed by Ventricular Septal Defect (VSD) (17), Patent Ductus Arteriosus (PDA) (11) and Tetralogy Of Fallot (TOF) (7).

In adolescent and young adults RHD was the most common finding, 546 out of 1094(49.90\%). Normal findings, Hypertensive heart disease, Congenital Heart Disease ,Pericardial Disease were 255(23.30\%), 146(13.34\%), $72(6.58 \%)$ and $48(4.38 \%)$ respectively.

In middle age group the most common finding was Corpulmonale 589 out of 1694(34.76\%). Followed by Diastolic Dysfunction 349(20.60\%), Hypertensive Heart Disease 289(17.06\%), Ischemic Heart disease 217(12.80\%), Systolic Dysfunction 179(10.56\%), Degenerative Valvular Disease $96(5.66 \%)$ and Normal findings 57(3.36\%) respectively.

In elderly age group most common finding was Diastolic Dysfunction 212 out of 371 (57.14\%). Followed by Hypertensive Heart Disease 169(45.55\%), Cor-pulmonale 137(36.92\%), Systolic Dysfunction 136(36.66\%), Degenerative Valvular Disease 117(31.54\%), Ischemic Heart disease 96(25.87\%) and Normal findings 5(1.34\%) respectively.

Common echocardiographic findings according to different age group are shown in table 3. 
Table 1 : Distribution according to age and sex

\begin{tabular}{|c|c|c|c|c|}
\hline \multirow[t]{2}{*}{ Age } & \multicolumn{3}{|c|}{ Number of patients } & P value \\
\hline & $\begin{array}{c}\text { Male } \\
(\mathrm{n}=1680)\end{array}$ & $\begin{array}{c}\text { Female } \\
(n=1630)\end{array}$ & $\begin{array}{c}\text { Total }(\%) \\
(n=3310)\end{array}$ & 0.44 \\
\hline $0-10$ & 72 & 79 & $151(4.56)$ & 0.34 \\
\hline $11-20$ & 136 & 152 & $288 \quad(8.70)$ & 0.03 \\
\hline $21-30$ & 164 & 151 & $315 \quad(9.51)$ & 0.23 \\
\hline $31-40$ & 251 & 240 & $491(14.83)$ & 0.31 \\
\hline $41-50$ & 370 & 342 & $712(21.51)$ & 0.02 \\
\hline $51-60$ & 480 & 502 & $982(29.67)$ & 0.01 \\
\hline $61-70$ & 128 & 103 & 231 (6.98) & 0.08 \\
\hline $71-80$ & 53 & 46 & 99 (2.99) & 0.42 \\
\hline $81-90$ & 21 & 14 & 35 (1.06) & 0.06 \\
\hline $91-100$ & 5 & 1 & $6(0.18)$ & 0.01 \\
\hline
\end{tabular}

Table 2: Echocardiographic finding in children (age 0 to 10years)

\begin{tabular}{|c|c|c|}
\hline $\begin{array}{l}\text { Echocardiography } \\
\text { findings }\end{array}$ & $\begin{array}{c}\text { Number of } \\
\text { patient }\end{array}$ & Percentage \\
\hline Congenital Heart disease & 57 & 37.74 \\
\hline ASD & 32 & \\
\hline VSD & 17 & \\
\hline PDA & 11 & \\
\hline $\mathrm{OF}$ & 2 & \\
\hline Other & 7 & \\
\hline Normal & 32 & 21.19 \\
\hline Pericardial Disease & 29 & 19.21 \\
\hline Rheumatic Heart Disease & 27 & 17.88 \\
\hline Other & 6 & 3.97 \\
\hline
\end{tabular}

Fig 1 : Common Echocardiograph findings in adolescents and young adults (age 11-40)

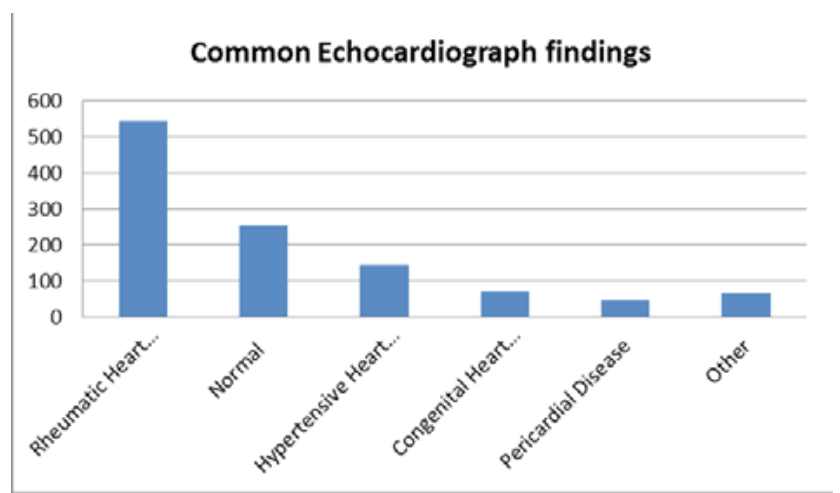

Fig 2 : Common echocardiograph findings in middle age (age 41-60)

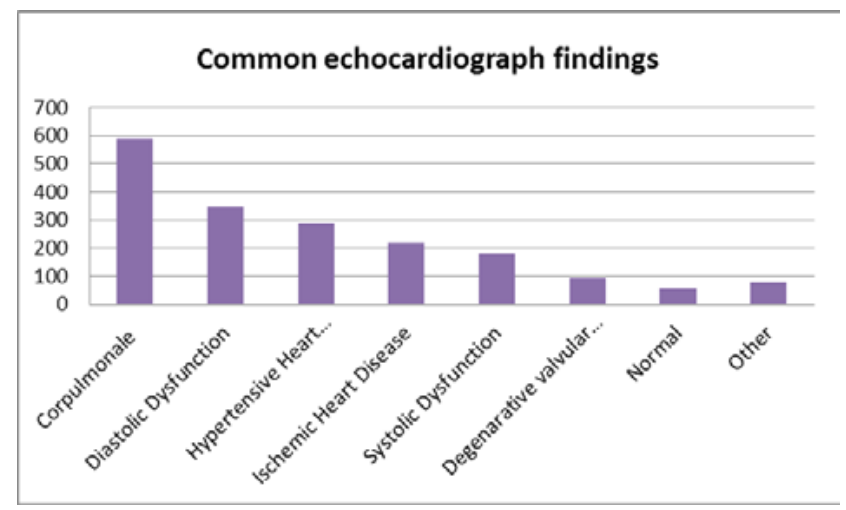

Fig 3 : Common echocardiograph findings in Elderly (age 61-100)

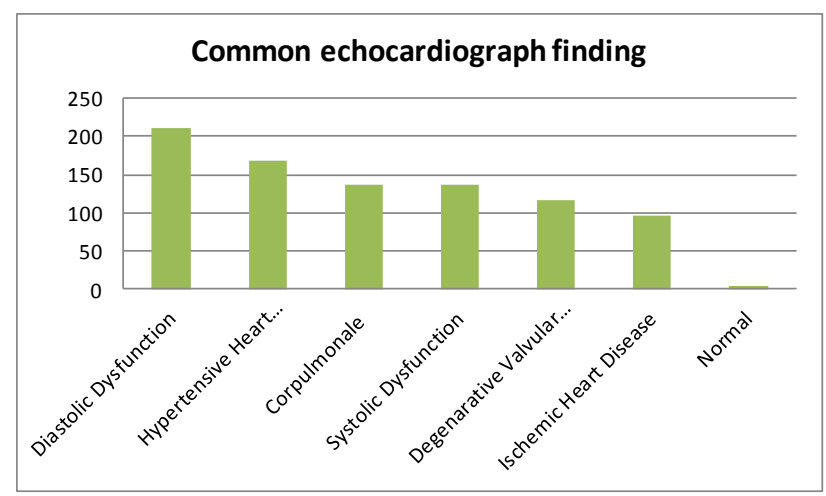


Table 3 : Most common echocardiograph findings in different age

\begin{tabular}{|c|c|c|c|}
\hline \multicolumn{4}{|c|}{ Common echocardiograph findings } \\
\hline Age & $\begin{array}{c}\text { 1st } \\
\text { Number (\%) }\end{array}$ & $\begin{array}{c}\text { 2nd } \\
\text { Number(\%) }\end{array}$ & $\begin{array}{c}\text { 3rd } \\
\text { Number (\%) }\end{array}$ \\
\hline $0-10$ & $\begin{array}{c}\text { Congenital } \\
57(37.74)\end{array}$ & $\begin{array}{l}\text { Normal } \\
32(21.19)\end{array}$ & $\begin{array}{c}\text { Pericardial } \\
29(19.21)\end{array}$ \\
\hline $11-20$ & $\begin{array}{c}\text { RHD } \\
134(46.53)\end{array}$ & $\begin{array}{c}\text { Normal } \\
68(23.61)\end{array}$ & $\begin{array}{c}\text { Congenital } \\
41(14.23)\end{array}$ \\
\hline $21-30$ & $\begin{array}{c}\text { RHD } \\
206(65.39)\end{array}$ & $\begin{array}{l}\text { Normal } \\
56(17.7)\end{array}$ & $\begin{array}{c}\text { Congenital } \\
26(8.25)\end{array}$ \\
\hline $31-40$ & $\begin{array}{c}\text { RHD } \\
216(51.55)\end{array}$ & $\begin{array}{c}\text { Normal } \\
131(26.68)\end{array}$ & $\begin{array}{c}\text { Hypertensive } \\
76(15.47)\end{array}$ \\
\hline $41-50$ & $\begin{array}{c}\text { Corpulmonale } \\
241(33.84)\end{array}$ & $\begin{array}{c}\text { DD } \\
150(21.06)\end{array}$ & $\begin{array}{c}\text { Hypertensive } \\
97(13.6)\end{array}$ \\
\hline $51-60$ & $\begin{array}{c}\text { Cor-pulmonale } \\
348(35.43)\end{array}$ & $\begin{array}{c}\text { DD } \\
199(20.26)\end{array}$ & $\begin{array}{c}\text { Hypertensive } \\
189(19.24)\end{array}$ \\
\hline $61-70$ & $\begin{array}{c}\text { DD } \\
140(60.60)\end{array}$ & $\begin{array}{c}\text { Cor } \\
\text { pulmonale } \\
121(52.38)\end{array}$ & $\begin{array}{c}\text { Hypertensive } \\
110(47.61)\end{array}$ \\
\hline $71-80$ & $\begin{array}{c}\text { DD } \\
61(61.61)\end{array}$ & $\begin{array}{c}\text { SD } \\
51(51.51)\end{array}$ & $\begin{array}{c}\text { IHD } \\
45(45.45)\end{array}$ \\
\hline $81-90$ & $\begin{array}{c}\text { Degenerative } \\
\text { Valve } \\
32(91.42)\end{array}$ & $\begin{array}{c}\text { IHD } \\
25(71.42)\end{array}$ & $\begin{array}{c}\text { SD } \\
17(48.57)\end{array}$ \\
\hline $91-100$ & $\begin{array}{c}\text { Degenerative } \\
\text { Valve } \\
5(83.33)\end{array}$ & $\begin{array}{c}\text { IHD } \\
3(50.00)\end{array}$ & $\begin{array}{c}\text { SD } \\
2(33.33)\end{array}$ \\
\hline
\end{tabular}

RHD-Rheumatic heart disease, DD-Diastolic dysfunction, SD-Systolic dysfunction, IHD -Ischemic heart disease

\section{DISCUSSION}

There was almost equal number of male and female patients in this study. However in some study there is predominant number of male patient ${ }^{9}$ and some shows predominant female patient. CHD is the most common finding in children similar to other studies ${ }^{9,10}$. ASD was the most common CHD in our study similar to Ejim EC et al. but most of the studies shows VSD to be the most common finding ${ }^{11-14}$.This is probably because we did not screen all the children for CHD and also we referred many cases to the pediatric cardiologist in other center when it was difficult for us to give our opinion. RHD is the most common finding in adolescents and young adults which is similar to the other studies from developing nations ${ }^{9,10}$ but different from those of developed nations ${ }^{1,2}$. This is a known fact that RHD is common in developing countries but almost nonexistent in developed countries ${ }^{5,15}$. Cor-pulmonale is the most common finding in middle age group in our study. We could not find this in other studies ${ }^{9,10}$, this is probably because our study is based on general hospital with multiple discipline rather than cardiac center and cor-pulmonale is a complication of respiratory disease which is common problem in Nepal ${ }^{5,6}$. Diastolic Dysfunction, Hypertensive heart disease, Degenerative valve disease, Ischemic heart disease, Systolic Dysfunction are all commonly found in elderly similar to other studies ${ }^{9,10}$.

\section{CONCLUSION}

From this study we can conclude there is a large spectrum of echocardiograph finding in a medical college hospital. In a developing country like Nepl, streptococcal sore throat leading to rheumatic heart disease and complication of tuberculosis and parasitic infestation leading to pericardial diseases, as well as the non- communicable diseases like hypertensive heart disease, and ischemic IHD still constitutes a huge burden. Cor-pulmonale and right heart failure are also common in our country and will definitely require more focus and evaluation in the future. 


\section{REFERENCES}

1. Anthony N DeMaria, Daniel G. Blanchard. The Echocardiogram. In Hurst's The Heart, the Mac Graw Hill companies 11th edition, 2004: 351-466

2. Heidi M. Connolly,Jae K. Oh. Echocardiography. In Braunwald- Heart Disease- A Textbook of cardiovascular medicine, Elseviers Saunders 9th edition, 2012: 203-270

3. Catherine M. Otto. Textbook of Clinical Echocardiography, Elseviers saunders, 4th ed, 2009: 1-30

4. Goonewardena SN, Gemignani A, Ronan A, et al: Comparison of hand-carried ultrasound assessment of the inferior vena cava and N-terminal pro-brain natriuretic peptide for predicting readmission after hospitalization for acute decompensated heart failure. Am J Coll Cardiol Img 2008; 1(5):595601 http://dx.doi.org/10.1016/j.jcmg.2008.06.005

5. World Health Organization : The Global Burden of Disease: 2004 Update. Geneva, World Health Organization, 2008

6. In: Lopez AD, Mathers CD, Ezzati M, et al ed. Global Burden of Disease and Risk Factors, New York: World Bank Group; 2006,2nd Edition:552-567

7. Shakya S, Sharma D, Bhatta YD et al, Current Scenario of Heart Disease in Nepal: At a glance . Nepalese Heart Journal 2011, 8:23-26.

8. Cheitlin MD, Armstrong WF, Aurigemma GP, Beller GA, Bierman FZ, Davis JL,et al. ACC/ AHA/ASE 2003 guideline update for the clinical application of echocardiography: Summary article: A report of the American College o Cardiology/American Heart Association Task Force on Practice Guidelines (ACC/AHA/ASE
Committee to Update the 1997 Guidelines for the Clinical Application of Echocardiography). Circulation 2003;108: 1146-1162. http://dx.doi. org/10.1161/01.CIR.0000073597.57414.A9

9. Ejim EC, Ubani-Ukoma CB, Nwaneli UC, Onwubere BJ. Common echocardiographic abnormalities in Nigerians of different age groups. Niger J Clin Pract 2013;16(3):360-364. http:// dx.doi.org/10.4103/1119-3077.113464

10. Ahmadou M Jingi, Jean Jacques N Noubiap et al. The spectrum of cardiac disease in the West Region of Cameroon: a hospital-based crosssectional study International Archives of Medicine 2013, 6:44-53

11. Kapoor R, Gupta S. Prevalence of congenital heart disease, Kanpur, India. Indian J Pediatric 2008;45:309-11

12. Mitchell SC, Korones SB, Berendes HW. Congenital heart disease in 56,109 births. Incidence and natural history. Circulation 1971;43: 323-332. http://dx.doi.org/10.1161/01. CIR.43.3.323

13. Hoffman JI, Christianson R. Congenital heart disease in a cohort of 19,502 births with long-term follow-up. Am J Cardiol 1978; 42:641-647. http:// dx.doi.org/10.1016/0002-9149(78)90635-5

14. Perry LW, Neill CA, Ferencz C. Epidemiology of Congenital Heart Disease: The BaltimoreWashington Infant Study 1981-1989. Mount Kisco, NY: Futura; 1993: 33-61

15. Humagain S, Gurung R, Pant P, Koju R, Bedi TRS. Pattern of Valvular Involvement and Demographic features of Patients on Injection Benzathine Peniciiln at Dhulikhel Hospital: Nepalese Heart Journal 2012;9:16-19 